\title{
VALUATION FOR PURPOSES OF THE FEDERAL TRANSFER TAXES -WHEN SHOULD THE TREASURY REGULATION'S ACTUARIAL TABLES BE USED?
}

The Internal Revenue Code of 1954 requires that property be valued either as of the decedent's death ${ }^{1}$ or as of the alternate valuation date one year later ${ }^{2}$ for purposes of the estate tax, and as of the date of the gift ${ }^{3}$ for purposes of the gift tax. One recurring problem involves the valuation of annuities, life estates, remainders, and reversionary interests. The Internal Revenue Service has provided tables of probability ${ }^{4}$ to be used in computing the present worth of such property interests. These tables are only estimates based on the current return on a safe investment as of the time the tables were compiled. 5 The mortality tables must also estimate the average life expectancy

1 INT. REv. CODE OF 1954, $\$ 2031$ (a). "The value of the gross estate of the decedent shall be-determined by including to the extent provided for in this part, the value at the time of his death of all property. ..."

" 2 INT. REv. CODE OF 1954, § 2032. "(a) General.-The value of the gross estate may be determined, if the executor so elects, by valuing all the property included in the gross estate as follows:

"(1) In the case of property distributed, sold, exchanged, or otherwise disposed of, within I year after the decedent's death such property shall be valued as of the date of distribution, sale, exchange, or other disposition.

"(2) In the case of property not distributed, sold, exchanged, or otherwise disposed of, within 1 year-after the decedent's death such property shall be valued as of the date 1 year after the decedent's death.

"(3) Any interest or estate which is affected by mere lapse of time shall be included at its value as of the time of death (instead of the later date) with adjustment for any difference in its value as of the later date not due to mere lapse of time.

"(b) Special Rules.- No deduction under this chapter of any item shall be allowed if allowance for such item is in effect given by the alternate valuation provided by this section. Wherever in any other subsection or section of this chapter reference is made to the value of property at the time of the decedent's death, such reference shall be deemed to refer to the value of such property used in determining the value of the gross estate. In case of an election made by the executor under this section, then-

"(1) for purposes of the charitable deduction under section 2055 or 2106(a)(2), any bequest, legacy, devise, or transfer enumerated therein, and

"(2) for the purpose of the marital deduction under section 2056, any interest in property passing to the surviving spouse, shall be valued as of the date of the decedent's death with adjustment for any difference in value (not due to mere lapse of time or the occurrence or nonoccurrence of a contingency) of the property as of the date 1 year after the decedent's death (substituting, in the case of property distributed by the executor or trustee, or sold, exchanged, or otherwise disposed of, during such 1-year period, the date thereof.)"

3 INT. REv. CODE of 1954, $\$ 2512$ (a). "If the gift is made in property, the value thereof at the date of the gift shall be considered the amount of the gift."

4 Treas. Reg. § 20.2031-7(f) (1958); Treas. Reg. § 25.2512-5(f) (1958).

5 Henry F. DuPont, 2 T.C. 246, 260 (1943). Problem (2), infra at 735, seems to be caused in part because the rate is seldom changed. The rate was changed in Treas. Reg. $\$ 105$ (1939), and again in 1952. See note 57, infra. 
of any age group. 6 Difficult cases will continue to arise, however, whenever the estimates seem to be inapplicable to the particular facts. ${ }^{7}$ In this context two main problems arise: (1) Should events occurring subsequent to the valuation date ${ }^{8}$ be considered in valuing an interest as of such date? (2) Should facts, known at the valuation date, which indicate a substantial variance from the tables, be considered in valuing an interest as of such date?

\section{I}

A deduction is allowed from the gross estate of a decedent for the value of property included in his estate and transferred by will in the form of bequests to charity. ${ }^{9}$ In Ithaca Trust Co. v. United States, 10 the decedent died

6 For an explanation of how life expectancy is determined, see UNITED States LIFE Tables and Actuarial Tables 1939-1941, Grevilie, U.S. Dept. of Commetce 138-43 (1946).

7 There are recognized actuarial tables other than those in the regulations, for example, on the probability of remarriage. See Pompeo M. Maresi, 6 T.C. 582, aff'd 156 F.2d 929 (2d Cir. 1946). The problems are the same there, and the discussion which follows would seem to be applicable to all recognized actuarial tables.

${ }^{8}$ The discussion of this problem which follows is applicable whether the date of valuation is the date of the gift, the date of the decedent's death or the alternate valuation date. Additional problems, though of a different nature, are raised if the events in question occurred between the decedent's death and the alternate valuation date one year later.

Assume A owns property worth $\$ 200,000$. During his lifetime he transfers a life estate to $B$. A then dies, leaving the reversion to charity. A's executor chooses the alternate valuation date. At A's death, B's life estate is worth $\$ 50,000$, but he dies one month later after receiving only $\$ 5,000$. In valuing the reversionary interest, section 2032(a)(3), quoted supra note 2 , is applicable because Treas. Reg. $\$ 20.2032-1$ (f) (1958) provides that a reversion is an interest affected by a mere lapse of time. Under 2032(a)(3) the interest shall be included at its value as of the time of death, adjusted for any difference in value not due to a mere lapse of time. Death of the life tenant is not due to a mere lapse of time. John A. Hance, 18 T.C. 499 (1952); Judson C. Welliver, 8 T.C. 165 (1947) (dictum). Therefore, the estate should include $\$ 195,000$, the value at the decedent's death $(\$ 150,000)$, adjusted for the difference in value caused by the death of the life tenant $(\$ 45,000)$.

However, for purposes of computing the charitable deduction, section 2032(b)(1), quoted supra note 2, requires that the bequest be valued as of the decedent's death, adjusted for any difference in value not due to a mere lapse of time or the occurrence or nonoccurrence of a contingency. Since it has been said that the death of the life tenant is the occurrence of such a contingency, the estate will be allowed a deduction only for the value of the bequest judged as of the decedent's death. Although the $\$ 195,000$ actually. transferred to charity is all included in the estate under 2032(a)(3), the estate receives only a $\$ 150,000$ deduction. For further discussion of this anomaly, see Price, Alternate Valuation Date Problems, N.Y.U.17rH INST. ON FED. TAX 1245 (1959). It would appear that this problem will arise infrequently since it may be avoided by choosing to value the estate as of the decedent's death. However, the tax savings resulting from the use of the alternate valuation date for other items may sufficiently offset the loss in this situation to justify the use of the later date.

9 INT. REv. CODE OF 1954, § 2055(a). "In General.—For purposes of the tax imposed by section 2001, the value of the taxable estate shall be determined by deducting from the value of the gross estate the amount of all bequests, legacies, devices, or transfers (including the interest which falls into any such bequest, legacy, devise, or transfer as a result of an irrevocable disclaimer of a bequest, legacy, devise, transer, or power, if the disclaimer is made before the date prescribed for the filing of the estate tax return)....

"For purposes of this subsection, the complete termination before the date prescribed 
testate, leaving the residue of his estate in trust, with instructions to pay the income to his wife for life and at her death to distribute the corpus to recognized charities. Since the valuation of the gift to charity depended upon the estimated longevity of the life tenant, it was necessary to value the life estate.11 The life tenant, though healthy at her husband's death, died within the year allowed to file the return. The Supreme Court held that the life tenant's expectancy was to be estimated by use of the mortality tables, and the fact, now known to the Court, of her actual life span was ignored. The Court reasoned as follows:

The estate so far as may be is settled as of the date of the testator's death. ... The tax is on the act of the testator not on the receipt of property by the legatees.... Therefore, the value of the thing to be taxed must be estimated as of the time when the act is done. But the value of property at a given time depends upon the relative intensity of the social desire for it at the time, expressed in the money that it would bring in the market.... Like all values, as the word is used in the law, it depends largely on more or less certain prophecies of the future; and the value is no less real at the time if later the prophecy turns out false than when it comes out true.12

The problem is the meaning of the term "value." The Treasury Regulations define value, for every item of property which is the subject of a gift or which is includible in a decedent's estate, as "the price at which the property would change hands between a willing buyer and a willing seller, neither being under any compulsion to buy or to sell." 13 In addition, the hypothetical buyer and seller are deemed to possess a reasonable knowledge of the facts. 14 The test is an objective one; therefore, any fact relevant to the question of value is admissible even though the parties may not have had actual knowledge of the fact.15

for the filing of the estate tax return of a power to consume, invade, or appropriate property for the benefit of an individual before such power has been exercised by reason of the death of such individual or for any other reason shall be considered and deemed to be an irrevocable disclaimer with the same full force and effect as though he had filed such irrevocable disclaimer.".

10279 U.S. 151 (1929).

11 A remainder, in this case the charitable deduction, is computed by valuing the life estate and then deducting the life estate from the total value of the property. This is now done by column II of the mortality tables.

12 Ithaca Trust Co. v. United States, 279 U.S. 151, 155 (1929). This case also considered whether the limits on the power to consume given to the life tenant provided a sufficiently ascertainable standard to allow valuation of the remainder for purposes of the charitable deduction. See the discussion of this problem in Commissioner v. Estate of Sternberger, 348 U.S. 187 (1955), and Mertens, Federal Gift AND Estate TAXation, § 28.37 (1960).

13 Treas. Reg. § 20.2031-1(b) (1958); Treas. Reg. § 25.2512-1 (1958).

14 E.g., O'Malley v. Ames, 197 F.2d 256 (8th Cir. 1952) (valuation of stock); Phillips v. United States, 12 F.2d 598 (W.D. Pa. 1926) (valuation of stock). See Gordon, What is Fair Market Value?, 8 TAX L. Rev. 35 (1952). See also Eisele, Valuation of Closely Held Stocks, 5. W. RES. L. REV. 37 (1953).

15 WARren \& SurRey, Federat Estate and Gift Taxation 610 (1961). 
The Supreme Court in Ithaca reasoned that value is a measure of what the interest would bring if there were a market for it at the time. The intensity of the demand in this market depends upon estimates of the future. If these estimates later prove to be invalid, the value will change. However, a purchaser cannot claim he did not receive full value because there is a change at a later date. For example, if A purchases a car from B for $\$ 2,500$, and one year later the car is hit by a truck and demolished, A cannot refuse to make further payments on the car. To argue that, because the car only lasted one year, it was therefore only worth $\$ 500$ at the purchase date would be ridiculous. Similarly, a purchaser of a life estate could not complain if the life tenant died sooner than expected. He bought the right to payments in the future which cannot be valued in retrospect.

Though it appears that Ithaca's reasoning should apply generally to the valuation of any future payment, 16 its application has been limited by the lower courts, even in the estate tax area. ${ }^{17}$ It has been suggested that if Ithaca were decided for the first time today, the Court, because of a change in the 1954 Code, would value the charitable remainder as of the death of the life tenant rather than at the decedent's death. 18 ,

Ithaca has been generally ignored in the valuation of claims against the estate. ${ }^{19}$ For example, in Commissioner $v$. Estate of Shively, 20 the decedent had agreed to pay his ex-wife alimony of forty dollars per week for her life or until her remarriage. The payments were to be binding on his estate. Within

16 The Court said "the estate so far as may be is settled as of the date of the testator's death." 279 U.S. at 155.

17 In Jacobs v. Commissioner, 34 F.2d 233 (8th Cir. 1929), decided just three months after Ithaca, the court said that Ithaca is applicable only to charitable deductions.

18 Note, 49 CALIF. L. REv. 378, 381 (1961). This suggestion is made because of the last sentence of section 2055(a), quoted supra note 9, which was first included in the 1954 Code. Assume that, in Ithaca, the total estate was $\$ 500,000$, the life estate was-worth $\$ 200,000$, but the wife died after receiving only $\$ 10,000$. It is suggested that under 2055(a), the death of the life tenant constitutes a complete termination of a power to consume, and it therefore operates as an irrevocable disclaimer. It is further said that the $\$ 190,000$ which goes to charity after the death of the life tenant is an "interest which falls into . . . such bequest . . . as a result of an irrevocable disclaimer." Since section 2055(a) allows the charitable deduction to be increased by any such interest, the estate would be allowed a $\$ 490,000$ deduction rather than the $\$ 300,000$ the Court actually allowed.

This suggestion does not seem valid on two grounds. First, it may be argued that, since the Court held that the possibility of invasion of corpus, judged at the decedent's death, was negligible, the life tenant, in effect, had no power to consume. In addition, under 2055(a), the deduction may be increased only by any interest which falls into the bequest as a result of the irrevocable disclaimer. Even assuming there is a power to consume, there is no increase of the bequest as a result of the disclaimer of that power. The additional $\$ 190,000$ which now goes to charity does so as a result of the death of the life tenant sooner than expected. If there had never been a power to consume, the bequest would have been $\$ 300,000$, so it seems clear that disclaiming such a power can result in no greater benefit.

19 INT. ReV. CODE of 1954, §2053(a)(3).

20276 F.2d 372 (2d Cir. 1960). 
the time allotted for the filing of the estate tax return, 21 decedent's ex-wife remarried. The Second Circuit held that, although the present value of the payments to be made could be reasonably ascertained as of the decedent's death, 22 the estate would be allowed a deduction only for the actual payments. Although there are contrary decisions, Shively represents the majority view. ${ }^{23}$

It has been argued that, since the net estate cannot be entirely ascertained from facts known at the time of death, subsequent events should always be considered. ${ }^{24}$ However, it would seem that one all-inclusive answer will not be satisfactory because there are two inherently different types of deductions: (1) expenses 25 and losses 26 incurred during the settlement of the estate; and (2) claims against the estate and charitable bequests.27 The first type cannot be valued at the time of death. There is no experiential data on which to rely, and to attempt an estimate would be to make a completely baseless guess. The reasoning of Ithaca seems to indicate clearly that future payments of the second type may and should be valued on the basis of actuarial tables at the time of death. ${ }^{28}$ It has been argued by a circuit court that, even though the claim was a liability capable of valuation at the time of death, Congress has evidenced an intent that final determination of the amount of the claim wait until the return is filed. ${ }^{29}$ Since claims against the estate are placed in the

21 The return must be filed within fifteen months after the decedent's death. INT. REv. CODE OF 1954, $\$ 6075$.

22 Pompeo-M. Maresi, 6 T.C. 582 (1946), aff'd 156 F.2d 929 (2d Cir. 1946).

${ }^{23}$ Accord, Commissioner v. State Street Trust Co., 128 F.2d 618 (1st Cir. 1942); Jacobs v. Commissioner, 34 F.2d 233 (8th Cir. 1929); Edyth v. Young, 29 B.T.A. 230 (1939). Contra, Winer v. United States, 153 F. Supp. 941 (S.D.N.Y. 1957); W. A. May, 8 T.C. 1099 (1947); Joseph Whittman, 21 P-H Tax. Ct. Mem. 584 (1952).

For discussions of the conflict favoring the Shively decision, see Note, supra, note 18, and.Note, 1961 DuKE L.J. 474.

24 Boston Safe Deposit and Trust Co. v. Nichols, 18 F.2d 660 (D.C. Mass. 1927). This case was decided prior to the Ithaca decision.

25 INT. Rev. CODE of 1954, § 2053(a)(1) and (2).

26 INT. REv. CODE OF 1954, § 2054.

27 It has been suggested that there is a conceptual difference between these two deductions. A gift to charity is an "element" of the estate. Since the gross estate must be valued as of the date of death, every part of it, whether deductible or not, should be valued at the same time. In claims against the estate, it is contended, the quantity being measured is not a portion of the estate, but an obligation the estate must discharge. Note, supra note 18, at 380.

It is not clear what this suggestion means. For purposes of inclusion, all the property is an "element" of the estate, no matter to whom it will be later distributed. For purposes of deduction, the amount to be taken from the estate, whether for a charitable bequest, or for a claim, must be valued. If its value requires an estimate of the future, that estimate must be made as of the valuation date.

28 Commissioner v. Estate of Sternberger, 348 U.S. $187^{\circ}$ (1955); Humes v. United States, 276 U.S. 487 (1928). 23.

29 Jacobs v. Commissioner, 34 F.2d 233. (8th Cir. 1929). See generally Notes, supra note 
same subsection as funeral and administrative expenses, it is argued that Congress intended that they be handled in the same way. However, congressional intent as to the method of valuation is certainly not clear. 30

Valuing claims in the way required by the Shively court presents difficulties. (1) If the life tenant dies the day before the return is filed rather than the day after, a fortuitously extreme variation in the tax due may result. (2) To consider such events would be an incentive for collusion. For example, in Shively the temptation would be great for the executor to pay the ex-wife to postpone her marriage until the return could be filed. It is probable that Congress would not intend to create the anomaly which results from allowing subsequent events to be considered. Assume that A dies leaving a $\$ 100,000$ estate. The residue of the estate is to go to charity. A's ex-wife has an enforceable claim against the estate for alimony payments valued at $\$ 20,000$, but she dies before the return is filed, after having received only $\$ 1,000$. Under Shively the estate would be allowed only $\$ 1,000$ deduction for the claim of the ex-wife. However, under Ithaca the estate would be allowed only an $\$ 80,000$ deduction for charity, leaving $\$ 19,000$ of the estate to be taxed $(\$ 100,000-\$ 81,000)$. The entire value of the estate could not be deducted, even though it was mandatory under the terms of the will that the entire estate be used for deductible purposes and even though it was in fact so used. ${ }^{31}$ In the face of these difficulties, we should not infer a congressional intent that is not clear.

In Nourse v. Riddell, 32 a district court completely ignored Ithaca, saying it was inapplicable. The decedent and her children had each transferred property to a trust, the income from which was to be paid to the decedent for her life, the corpus to the children at her death. The Internal Revenue Code of $1954, \S 2036$, includes in the transferor's estate any property in which she retains a life estate unless she received adequate consideration for her transfer. At the date of transfer, the decedent had a life expectancy of seven years. The income for seven years from the property contributed by the children was not adequate consideration for the interest she transferred to the trust. The decedent actually lived thirteen years after the transfer. Since the income for thirteen years from the property contributed by the children was adequate consideration, the court held that nothing was includible in the decedent's estate. The mortality tables were said to be merely evidentiary, and inapplicable here because the actual facts were now known. One com-

${ }^{30} \mathrm{~A}$ joint committee prior to the enactment of these statutes did recommend that some means be found to allow for an increase or decrease in value subsequent to the valuation date, but nothing further was ever said. Federal and STATE Death TAXEs 164 (1933) [Reports to the Joint Committee on Internal Revenue Pursuant to Sec. 1203(b)(6), Revenue Act of 1926, Vol. II, Part 2 (1933)]

31 See Note, 1961 DUKE L.J. 474.

32143 F. Supp. 759 (S.D. Cal. 1956). 
mentator has argued that there are now two definite and conflicting rules of valuation. 33 However, Nourse, in the six years since its decision, has been followed only once-by another district ${ }^{\circ}$ court, 34 and has been expressly rejected by a California court ${ }^{35}$ with respect to a state statute ${ }^{36}$ similar to the federal statute. In fact, Nourse should be disregarded because the authority it relies upon does not support the decision. ${ }^{37}$

Although the general problem discussed in this part occurs less frequently in the gift tax area, the Ithaca reasoning has prevailed there also. In Lockard v. Commissioner, ${ }^{38}$ the donor set up an irrevocable six-year trust. Income was to go to the donor's husband. In addition, the donor, as trustee, had the power to invade corpus up to $\$ 3,000$ per year for the benefit of the life tenant. The present value of $\$ 3,000$ per year was also taxed as a gift, although it was known when the tax was contested that the donor had not invaded corpus for the first four years.

The utility of the Ithaca reasoning is limited to cases of valuation based on actuarial experience. ${ }^{39}$ For example, in Whitlow v. Commissioner, 40 the tax-

33 See Note, 45 VA. L. REv. 1230, 1233 (1959).

34 Olson v. Reisimer, 170 F. Supp. 541 (1959), rev'd on other grounds, 271 F.2d 623 (7th Cir. 1959).

35 Estate of Stevens, 163 Cal, App. 2d 255, 329 P.2d 337 (1958).

36 CAI. REv. \& TAX. CODE $\$ \S 13643-45$.

37 Hanley v. United States, 63 F. Supp 73 (Ct. Cl. 1945); Huntington Nat'1 Bank v. Commissioner, 13 T.C. 760 (1949); Nellie H. Jennings, 10 T.C. 323 (1948); and John Denbigh, 7 T.C. 387 (1946) hold that facts known at the valuation date may be considered. See text beginning at p. 735 infra. Raymond v. Commissioner, 114 F.2d 140 (7th Cir. 1940), cert. denied, 311 U.S. 710, concerned the question of whether the tables were obsolete. It was admitted they would have been used if modernized.

There were cases prior to Ithaca to support the decision, however. Herold v. Kahn, 159 Fed. 608 (3d Cir. 1908) (subsequent death of life tenant considered); Herron v. Heiner, 24 F.2d 746 (W.D. Pa. 1927) (subsequent death of life tenant considered); Union Trust Co. v. Heiner, 19 F.2d 362 (W.D. Pa. 1927) (subsequent death of life tenant considered); Gunning v. Carman, 3 Redfield (N.Y. Surr. Ct.) 69 (1877) (assessment for permanent improvement. The life tenant died. He was charged only with the interest up to this death. The remainderman was charged the rest of the interest and the entire principal.). Contra, Foster v. Hilliard, 9 Fed. Cas. 549 (No. 4972) (C.C.D. Mass. 1840) (life tenant sold land with the consent of the remainderman but died before receiving the purchase price. The life tenant was held entitled to a share of the proceeds based on his life expectancy at the date of sale.).

38166 F.2d 409 (1st Cir. 1948).

${ }^{39} \mathrm{~A}$ somewhat analogous situation is presented in tort law. In an action for personal injury, damages for loss of earnings are based on the plaintiff's life expectancy immediately before the injury, but damages for pain and suffering are based on the plaintiff's probable life expectancy in his injured condition. Borcherding v. Eklund, 156 Neb. 196, 55 N.W.2d 643 (1952). In all situations, if the plaintiff has died before trial, his actual life span, rather than an estimate, is used. Atchison, T. \& S.F. R.R. v. Chance, 576 Kan. 40, 45 Pac. 60 (1896); Rouse v. Michigan United Ry. Co., 164 Mich. 475, 129 N.W. 719 (1911); Rogers v. Thompson, 364 Mo. 605, 265 S.W.2d 282 (1954).

The torts cases differ in that there is no attempt at valuation. There is an attempt to reimburse the injured party, as well as possible, for his actual losses. Therefore, all relevant information available at the date of trial should be considered. An estimate is required at the trial date only because of the inability of the courts to administer payments over the 
payer received promissory notes on the sale of his interest in an insurance company. In computing the gain on the sale, the Internal Revenue Service valued the notes at face value, but the taxpayer contended the notes were of little or no value at the time of sale because the makers' business prospects were uncertain. Since, at the time of trial, 80 per cent of the notes had come due and had been paid, the gain was computed at the face value of the notes. ${ }^{41}$ The problem seems to be analogous to Ithaca in that both require the valuation of payments to be made in the future; in Whitlow because full payment is doubtful and in Ithaca because the duration of the life payments is uncertain. The cases may be differentiated, however, on the basis of the experiential data available at the valuation date to aid in the computation. In Ithaca a mortality table was available as a basis for estimating life expectancy. When the actual life span became known it was not considered because the valuation had been reasonably made. In Whitlow the situation was similar to the valuation of funeral expenses considered earlier. There is no experiential data concerning the likelihood of payment of a note by its maker. There is only an estimate of what the experience will be in this particular case. When the actual facts became known, the comparison is not with a well reasoned estimate based on an average experience, but with a completely baseless guess. 42 In such circumstances it is logical to consider the actual facts.

In considering the problem of events occurring subsequent to the valuation date, it would seem, therefore, that the Ithaca reasoning, instead of being limited, should be expanded when there is data available to aid in making a reasonable valuation.

\section{II}

The second problem to be considered is whether facts, known at the valuation date, which indicate a variance from the tables should be considered in valuing an interest as of such date. It follows from the Ithaca reasoning that such facts should be considered if it is reasonably foreseeable at the time that they will cause a substantial variance. 43 If the auto buyer discussed previously was offered a car which he knew to have a serious defect which would limit its life to one year, he might offer only $\$ 500$, even though the average car of

actual life span of the victim. In contrast, in the tax area there is an attempt to value property as of a certain date. Subsequent changes in value are irrelevant. See text accompanying notes 12-16 supra. See Immel, Actuarial Tables and Damage Awards, 19 OHIO Sr. L.J. 240, 246-47 (1958).

4082 F.2d 569 (8th Cir. 1936).

$41 \mathrm{Id}$. at 571. Accord, Pokress v. Commissioner, 234 F.2d 146 (5th Cir. 1950 (subsequent rental of seemingly valueless property considered); Doric Apartment Co. v. Commissioner, 94 F.2d 895 (6th Cir. 1938) (subsequent payment of mortgage notes). Contra, Osgood Land \& Livestock Co., 22 B.T.A. 387 (1931) (subsequent sale of land at above-market price because of discovery of water not considered).

42 See text accompanying notes 24-28, supra.

3 See Jam̉es Couzens, 11 B.T.A. 1040 (1928). 
that age would last ten years, and therefore be valued at $\$ 2,500$. This problem arises in two contexts: (1) when the life tenant has an apparent physical defect at the valuation date; and (2) when the assets in the life estate are yielding a return substantially higher or lower than the $31 / 2$ per cent used by the regulations.

The Tax Court in Nellie H. Jennings 44 again faced the issue of the valuation of a remainder for purposes of the charitable deduction. 45 At the decedent's death, the life tenant was completely paralyzed, and had a total loss of memory. Doctors testified that he could not live more than a year. The court held the mortality tables inapplicable and valued the life estate with an expectancy of one year. ${ }^{46}$ It has been argued by a commentator that there is no authority for the courts to disregard the actuarial tables, ${ }^{47}$ since the tables seem applicable to the valuation of all future payments. It was also argued that there is no support for the proposition that the tables are evidentiary only48 and, therefore, that the limitation on the use of the tables is an attempt to impose judicial principles upon the Treasury Department. The regulations themselves, however, require the use of fair market value. 49 Since it is clear the value of a life estate in the open market would be much lower if the life tenant is mortally ill than if he is healthy, it would seem that the courts are strictly following the regulations.

The question of what variation from the average is necessary to render the tables inapplicable is common to all cases in this part. It would be possible to require expert testimony as to the valuation of each individual life estate, but that would merely bring back the administrative difficulties which the regulations sought to alleviate by the use of the tables. Therefore, it would seem that only a substantial variation should justify allowing either party to disregard the tables. The problem of what is substantial is, of course, difficult. The courts have not dealt with the problem, but, in each case where the

410 T.C. 323 (1948).

45 INT. REv. CODE OF 1954, § 2055(a), quoted supra, note 9.

46 Accord, John P. Hoelzel, 28 T.C. 384 (1957) (cancer, expectancy of not in excess of one year); James W. Douglas, 12 CCH Tax Ct. Mem. 347 (1953) (ulcerative colitis, "six months to a year"); Nicholas M. Butler, 18 T.C. 914 (1952) (cancer, "not more than one year"); T. C. Hendrick, 9 CCH Tax Ct. Mem. 581 (1950) (myocarditis, "six months to one year"); Huntington Nat'l Bank v. Commissioner, 13 T.C. 760 (1949) (cancer, "not greater than one year"); John Denbigh, 7.T.C. 387 (1946) (cancer, "within a year or so"); Dalton v. Campbell, 56-2 U.S. Tax. Cas. II 11,621 (1956) ("actual physical condition," expectancy of ten years). Cf. Kemper v. Donnelly, 55-1 U.S. Tax. Cas. I 11,511 (E.D. La. 1954); Palfrey v. United States, 36 F. Supp. 153 (D. Mass. 1940).

47 See Note, 51 Mrch. L. Rev. 760 (1953).

48 Nellie H. Jennings, 10 T.C. 323 (1948); John H. Denbigh. 7. T.C. 387 (1946).

49 The relevant portions of both the estate and gift tax regulations are the same. Treas. Reg. \$ 20.2031-7 (1958); Treas. Reg. \$25.2512-5 (1958). "The fair market value of annuities, life estates, terms for years, remainders and reversions is their present value, determined under this section....". 
variation was allowed, have simply stated that the variance was substantial. The great majority of the cases have concerned life tenants of very short life expectancy (in most cases less than one year), 50 and the life tenant has always confirmed the medical prognostication by dying within the period of actual expectancy. It has been suggested that one method of drawing the line of substantiality is to allow the use of actual life expectancy to supersede the use of the mortality tables only where the actual expectancy, at the valuation date, is less than the time allowed for the filing of the return, and where the life tenant has in fact died before the return is filed. 51

While this suggestion has the obvious advantage of certainty, it seems to sacrifice the principle which is the basis for allowing any variation. For example, in one Tax Court case, 52 the life tenant was only forty-four years old, and according to the mortality tables had a long life expectancy. It is not clear what illness she had, but the court used a ten-year life expectancy, based on medical testimony that that was her maximum foreseeable life span. Although the life expectancy is not here dramatically short, the same reasoning concerning "value" logically calls for a variation from the tables. As the length of the predicted life span increases, the uncertainty grows, but it seems logical to allow a deviation from the tables where there is still a reasonable certainty of a substantial variance.

In Palfrey v. United States, 53 a district court used the mortality tables despite the executor's contention that the life tenant was independently wealthy, without business cares or worries, and was apt to live beyond the expectancy predicted for him by the tables. This seems to be the case for which the tables were enacted; there is no reasonable certainty of a variance, nor is the predicted variance substantial.54

When the assumed interest rate is contested, the courts have been more willing to allow substitution of the actual facts than when the question has concerned use of an average life expectancy. 55 For example, in Huntington National Bank $v$. Commissioner, 56 the expected yield of the estate assets, based

so See cases cited, supra note 46.

51 Note, supra note 47.

52 Dalton v. Campbell, 56-2 U.S. Tax. Cas. ๆ 11,621 (1956).

5336 F. Supp. 153 (D. Mass. 1940).

${ }^{54}$ In Stillman (Tax. Ct. Docket No. 90320), the taxpayer made a gift of his interest in a trust. The taxpayer's interest was contingent upon surviving his sister and her dying without surviving descendants. At the date of the gift both taxpayer and sister were approximately fifty years old. The taxpayer contends that the gift should be valued according to the tables. The Internal Revenue Service contends that, since the sister has less than a year to live, her actual expectancy should be used. See $15 \mathrm{~J}$. TAXATION 127 (1961).

${ }^{55}$ E.g., "It is ... manifest that there is nothing sacred about the four percent rate used in the Treasury tables." Hanley v. United States, 63 F. Supp. 73 (Ct. Cl. 1945). Before January 1,1952 , the tables used a rate of four per cent. See note 57, infra.

5613 T.C. 760 (1949). 
on prior return, was $31 / 2$ per cent. (Until January 1,1952 , the rate used in the tables was 4 per cent rather than the present $31 / 2$ per cent.) ${ }^{57}$ The Tax Court held the tables inapplicable.58

The Internal Revenue Service and the taxpayers as a group have each been on both sides of the question whether the regulation's interest rate should be used. Each advocates strict accordance with the regulations only when its best interests are served. 59 This has been suggested as sufficient justification for strict application of the regulations. 60

To use the table's interest rate in all cases would allow manipulation by the parties. A taxpayer might transfer a work of art to a museum, retaining a life estate. 61 The actual value of the life estate is the cost to the taxpayer of renting the treasure for his lifetime. This rent would be far in excess of the $31 / 2$ per cent used by the tables. Since the value of the gift increases as the interest rate decreases, use of the lower table rate will leave the taxpayer with a larger charitable deduction for income tax purposes 62 than he is entitled to. Such an arrangement has the additional advantage in the estate tax area of increasing the taxpayer's marital deduction. 63 One half of the "adjusted gross". estate may go to the decedent's spouse free of estate tax. The adjusted gross estate is the gross estate less all deductions except the charitable deduction and the marital deduction. Therefore, a taxpayer's gifts to charity during his lifetime should, if possible, be in such a form that they will be brought back into his estate at death ${ }^{64}$ if he is married and has not used up his marital deduction. Such a plan is uncertain of success. It is not clear that the executor will be allowed to use to his advantage sections which bring property back into the estate, 65 since such sections were designed to

57 Treas. Reg. § 20.2031-7(f) (1958); Treas. Reg. § 25.2512-5(f) (1958).

58 Accord, Hanley v. United States, 63 F. Supp. 73 (Ct. Cl. 1945) (actual yield 3.09\%); Security-First Nat'l Bank of Los Angeles, 35 B.T.A. 815 (1937) (actual yield of 5\%). Cf. William Korn, 35 B.T.A. 1071 (1937). For a case where the variance was deemed insuffcient see, e.g., Irma E. Green, 22 T.C. 728 (1954) (actual yield of 4.34\%; pre-1952 regulations applicable).

59 See, e.g., John N. Lisle (Tax. Ct. Docket No. 88068), where the taxpayer transferred property and retained a life estate. The property was under a ten-year lease returning income in excess of $31 / 2$ per cent. To reduce the value of the remainder taxable as a gift, the taxpayer argued that the actual income should be used. If, however, the taxpayer had transferred the life estate and retained the reversion, then it would be the Service arguing for use of the actual return, thus increasing the value of the taxable gift.

6014 J. TAXATION 255 (1961).

61 See Rev. Rul. 57-293, 1957-2 Cum. BuL.. 153.

62 INT. REv. CODE OF 1954, § 170.

63 INT. REY. CODE OF 1954, 82056.

64 See Quiggle and Myers, Tax Aspects of Charitable Contributions and Bequests by Individuals, 28 FORDHAM L. REv. 579 (1959-60); Rudick and Gray, Bounty Twice Blessed: Tax Consequences of Gifts.of Property to or in Trust for Charity, 16 TAX L. REV. 273 (1961). 65 INT. Rev. CoDE of 1954, \$§ 2035-38. 
prevent manipulation and have until now only been used by the Internal Revenue Service. Even if the executor succeeds in bringing the property back into the estate, it is not clear that the charitable deduction will be allowed under the language of the Code. Charitable deductions are allowed for all "bequests, legacies, devises or transfers." 66 This gift is clearly not a bequest, legacy or devise. Since the property does not actually return to the probate estate, but is merely so treated for purposes of the estate tax, the gift may not even be considered a "transfer" at death. To so consider it is to use the "transfer at death" fiction which brought the property back into the estate under one group of sections, in the unrelated charitable deduction section where this approach has not yet been used.

Another common plan to avoid taxes is to transfer property to a shortterm reversionary trust. The property transferred is normally income-producing property yielding a return far in excess of $31 / 2$ per cent. The gift if valued by the tables will be smaller than the actual amount of income given. The income itself will be taxed, for income tax purposes, at the lower rates of the trust. ${ }^{67}$ In two cases presently before the Tax Court, ${ }^{68}$ the Internal Revenue Service is contending that the transfer for ten years and ninety days is not a gift of a term of years to be valued by the tables, but is rather a gift of a term of years in a "business interest" to be valued under general valuation principles on its particular yield. 69 This is an attempt by the Internal Revenue Service to develop another small exception to the general use of the actuarial tables, where their use would decrease the taxes due.

Since the rate used in the regulations is deemed to be the current return on a safe investment, 70 it would seem that the courts should freely allow the actual yield to be used where, for example, the investment is in speculative rather than conservative securities. ${ }^{71}$ However, it seems preferable to allow deviation from the tables only if the return is relatively certain to remain at the present level.72

66 INT. REv. CODE OF 1954, § 2055(a), quoted supra note 9.

67 INT. REv. CODE OF 1954, § 641.

68 Carl E. Weller (Tax Ct. Docket No. 86488); and Emily I. Weller (Tax Ct. Docket No. 86489).

${ }^{69}$ Treas. Reg. $\$ 25.2512-3$ (1958). There is a similar section for valuation of estates. Treas. Reg. \& 20-2031-3 (1958).

70 Henry F. DuPont, 2 T.C. 246, 260 (1943).

71 See $i d$. at 250.

${ }^{22}$ See, e.g., Smith v. Shaughnessy, 40 F. Supp. 19 (D.C.N.Y. 1941), where tables were used rather than the actual 6 per cent return because the secarities were convertible into securities with a lower return. 